\title{
Pensamento freireano em tempos de escola SEM PARTIDO
}

\author{
Moacyr Salles Ramos \\ Universidade Federal Fluminense (UFF), Niterói, Rio de Janeiro, \\ Brasil \\ Ana Cecília dos Santos Santoro \\ Centro Federal de Educação Tecnológica Celso Suckow da Fonseca \\ (CEFET/RJ), Rio de Janeiro, Brasil
}

\begin{abstract}
Resumo: O presente artigo apresenta uma breve reflexão acerca do pensamento de Paulo Freire, tendo como pano de fundo os debates que se travam sobre ele no contexto do Movimento Escola Sem Partido. Além disso, apresentamos documentos da ditadura militar que exemplificam a forma como o pensamento freireano era perseguido na época. Trata-se de uma análise que faz uso de fontes primárias e secundárias. Constatamos que, apesar de vivermos em momentos históricos distintos, as estratégias de perseguição parecem similares, sempre associando o pensamento de Paulo Freire a processos de doutrinação ideológica de esquerda. $\mathrm{Na}$ realidade, no pensamento freireano, a transferência/imposição de conhecimentos por parte dos professores, sob qualquer perspectiva político-ideológica, não encontra abrigo, pois, para ele, esta é a educação bancária.

Palavras-Chave: Paulo Freire. Escola Sem Partido. Ditadura militar. Doutrinação.
\end{abstract}

INTRODUÇÃO

"Subversivo", engajado em movimentos populares, famoso por alfabetizar 300 trabalhadores rurais em 45 dias no início dos anos 1960, Paulo 
Reglus Neves Freire, mais conhecido como Paulo Freire, foi convidado para planejar a alfabetização de adultos no governo do presidente João Goulart. Porém, foi preso no contexto do golpe de 1964. Após 72 dias de prisão, exilouse no Chile, passando por países como Bolívia, Suíça, São Tomé e Príncipe, Guiné-Bissau, dentre outros, e retornando para o Brasil em 1979. Em 2009, foi considerado anistiado político e, em 2012, reconhecido como patrono da educação brasileira.

Segundo o Dicionário Houaiss da língua portuguesa, "patrono" é aquele "que luta ou defende uma causa, ideia" e/ou "escritor, cientista, artista que uma classe de profissionais, uma academia (de ciências de letras etc.) ou outra instituição do gênero elege como tutor de cada uma de suas cadeiras" (HOUAISS, 2001, p. 2151). Em ambas as interpretações, Paulo Freire se encaixa perfeitamente, porém, é no campo da defesa de causas e ideias que seu nome tem sido constantemente citado atualmente, sendo a inspiração para muitos e algoz para outros.

Os que se inspiram no pensamento de Paulo Freire são, geralmente, sujeitos, trabalhadores da educação ou não, que se identificam com os pressupostos de uma educação libertadora, que se dá por meio de uma relação dialógica. No entanto, seu pensamento é temido e reprimido por aqueles que lutam por uma educação para a conformação dos sujeitos diante dos opressores. Essa bipolaridade parece se radicalizar dentro do atual cenário político brasileiro, marcado pelo fim de um período de três mandatos consecutivos do Partido dos Trabalhadores (PT) no governo federal e pela reivindicação de grupos que se sentem lesados por uma educação "pintada de vermelho", supostamente proposta por aquele partido.

No centro dos debates, articulam-se questões acerca da neutralidade e do fim das ideologias na escola. A esquerda é acusada de doutrinar os alunos, incutindo um leque de ideologias perniciosas, tanto marxistas quanto de gênero. A ideologia, seja no sentido de mentira, seja de falsa consciência, seja como conjunto das representações sociais ou ainda como visão de mundo, está sendo convidada a se retirar dos conhecimentos e processos de ensino, separando, assim, o processo histórico de produção do conhecimento dos sujeitos e realidades em que foram/ são construídos.

É exatamente nesse aspecto que Paulo Freire e seus seguidores têm sido alvo de inúmeros ataques. Referimo-nos à amplitude que tem tomado a campanha por uma "escola sem partido", que luta "contra o abuso da liberdade de ensinar". Esses movimentos de controle e criminalização do trabalho docente revelam, dentre outros fatores, que o processo de redemocratização do nosso país se deu por meio de um "gradualismo", típico de um modo de 
transição fraco (NOGUEIRA, 2004). Diante disso, grupos da sociedade civil, juntamente com sujeitos de categorias políticas, reivindicam uma educação neutra, acusando os professores de "doutrinadores esquerdistas" e chegando ao ponto de afirmar que o pensamento de Paulo Freire é uma doutrinação'.

Essa ofensiva contra a educação problematizadora não é uma novidade. É sabido que o mesmo aconteceu com o próprio Paulo Freire e diversos outros educadores durante a ditadura militar brasileira (1964-1985). O que nos chama a atenção é o lugar social que esse tipo de debate tem ganhado em um momento histórico tido como democrático.

Nessa direção, o propósito deste artigo é traçar um paralelo entre a perseguição que está sendo travada contra os docentes que se pautam no pensamento freireano hoje e a sofrida pelo próprio Paulo Freire durante a ditadura militar. Para tal, utilizamos documentos do Sistema Nacional de Informação (SNI), órgão de vigilância do regime de exceção². Análise similar à que propomos, porém, não tendo Paulo Freire como centro do debate, foi feita por Ramos \& Stampa (2016), em um artigo que compara a perseguição e o controle do trabalho docente durante a ditadura militar com o momento atual, no qual se debatem as propostas do Movimento Escola Sem Partido.

Nossa intenção é de contribuir com o debate acerca das possibilidades de uma educação problematizadora, sem, contudo, esgotar outras abordagens, já que o tema é controverso e ainda necessita de pesquisas mais amplas. Para tal intento, o texto está dividido em três partes, a saber: "O Movimento Escola Sem Partido e o pensamento freireano em confronto", "Paulo Freire nos documentos da ditadura" e "Considerações finais".

\section{O Movimento Escola Sem Partido e o pensamento freireano em con-} FRONTO

Em um debate realizado no dia 26 de julho de 2016, na TV Futura, o advogado Miguel Nagib, fundador e presidente do Movimento Escola Sem Partido, descreveu Paulo Freire como um pedagogo do Partido dos Trabalhadores (PT) que usou toda a pedagogia progressista para promover os interesses do partido. Na sequência, Nagib afirmou que o professor não tem o direito de exercer sua liberdade de expressão em sala de aula, pois, se assim o fizer, o aluno não terá direito de consciência e de crença, pois o aluno é uma audiência cativa do professor (NAGIB, 2016).

Assim, difunde-se que o problema da educação brasileira é a atuação de um "exército de professores doutrinadores", que se aproveitam da liberdade de cátedra e da audiência compulsória dos alunos para incutir suas posições ideológicas, além de desrespeitar a educação moral e religiosa das famílias. 
Esta é a interpretação da realidade defendida pelo Movimento Escola Sem Partido, que surgiu em 2004 e iniciou, a partir de 2014, a organização de projetos de lei (PLs).

A fim de "solucionar" o problema da doutrinação, o referido movimento tem organizado parte da sociedade civil em uma luta pela alteração da Lei de Diretrizes e Bases da Educação Nacional (LDB), a fim de que se inclua o Programa Escola Sem Partido nessa lei. Assim, o Movimento Escola Sem Partido tem fornecido os fundamentos teóricos para PLs que circulam no Senado Federal, na Câmara dos Deputados, em Câmaras Municipais e Assembleias Legislativas de várias partes do Brasil. Apesar de lutarem pelos mesmos objetivos, é importante esclarecer que o Movimento Escola Sem Partido é uma organização que atua na esfera da sociedade civil, enquanto o Programa Escola Sem Partido é a apresentação dos pressupostos do movimento em forma de PLs.

Os PLs que tramitam apresentam poucas variações, tendo sempre como principal pilar o controle do trabalho docente. Há projetos que pretendem tipificar o crime de "assédio ideológico", com pena de prisão de três meses a um ano, como o PL 1411/2015 (BRASIL, 2015a), de autoria do deputado Rogério Marinho, do Partido da Social Democracia Brasileira (PSDB). Além deste, destacamos o PL no 193/2016 (BRASIL, 2016), de autoria do senador Magno Malta, do Partido da República (PR), bem como o PL 867/2015 (BRASIL, 2015b), do deputado federal Izalci Lucas Ferreira, do PSDB. Esses dois projetos se complementam no que tange ao cerceamento docente diante das questões políticas, de gênero e submetem os processos pedagógicos às convicções religiosas e morais dos pais.

O Programa Escola Sem Partido já foi aprovado no estado do Alagoas ${ }^{4}$ e no município de Santa Cruz de Monte Castelo, no Paraná. Dentre outros pontos, ele pretende incluir na LDB os seguintes princípios: a) neutralidade política, ideológica e religiosa do Estado; b) vulnerabilidade do educando como parte mais fraca da relação de aprendizagem; c) educação moral e religiosa de acordo com as convicções dos pais; d) proibição de tratar de questões de gênero na escola, a fim de não interferir na identidade biológica do sexo; e) proibição para o professor de emitir sua opinião e convicções dentro da sala de aula; f) proibição de incentivar os alunos na participação da vida política e de tratar dos problemas atuais, como passeatas, protestos, etc.

As ações supracitadas criam a necessidade de um amplo sistema de vigilância do trabalho docente, que deve ser executado pelas secretarias e pelo Ministério da Educação. Esses órgãos teriam também o dever de apurar e encaminhar as denúncias anônimas para o Ministério Público Federal. Além 
disso, nas salas de aula de todo o Brasil, pretende-se afixar um cartaz com os deveres e as proibições para os professores. A abrangência desse programa alcançaria ainda as políticas e os planos educacionais, todos os materiais didáticos e paradidáticos, as avaliações para o ingresso no ensino superior, os concursos docentes e, por fim, as universidades (BRASIL, 2016).

Convém atentar que, mesmo sem a aprovação do Programa Escola Sem Partido, a atuação do Movimento Escola Sem Partido já tem sido suficiente para criar uma onda de perseguição docente no interior das instituições escolares. Por isso, têm sido cada vez mais comuns casos de professores afastados de suas funções por "atividade subversiva" e "doutrinação ideológica". Com base nas orientações dadas pelo movimento, alunos estão denunciando seus professores, num clima de desconfiança, descrédito e de elaboração de armadilhas, com gravação de vídeos e áudios escondidos, os quais, na maior parte dos casos, captam fragmentos de aulas, sem qualquer contextualização, buscando criminalizar qualquer trabalho de conscientização5. Para confirmar tal fato, basta acessar o Facebook do Movimento Escola Sem Partido, que parece funcionar como um tribunal pedagógico ${ }^{6}$, em que são divulgadas várias denúncias e rechaçados os supostos professores doutrinadores. No site do movimento, é possível ver o teor das orientações.

Na dúvida, não se precipitem. Planejem a sua denúncia. Anotem os episódios, os conteúdos e as falas mais representativas da militância política e ideológica do seu professor. Anotem tudo o que possa ser considerado um abuso da liberdade de ensinar em detrimento da sua liberdade de aprender. Registrem o nome do professor, o dia, a hora e o contexto. Sejam objetivos e equilibrados. Acima de tudo, verazes. E esperem até que esse professor já não tenha poder sobre vocês. Esperem, se necessário, até sair da escola ou da faculdade. Não há pressa. Quando estiverem seguros de que ninguém poderá lhes causar nenhum dano, DENUNCIEM a covardia de que foram vítimas quando não podiam reagir. Façam isso pelo bem dos estudantes que estão passando ou ainda vão passar pelo que vocês já passaram. É um serviço de utilidade pública (ESCOLA SEM PARTIDO, 2016).

Como exemplo de como o "serviço de utilidade pública" já tem sido executado, podemos citar o caso da professora de inglês Janeth de Souza, do Instituto de Educação Rangel Pestana, do município de Nova Iguaçu (RJ). Em novembro de 2015, após a aula, a professora recebeu um telefonema da diretoria de educação informando-a sobre a abertura de uma sindicância por conta de uma denúncia de "doutrinação ideológica". A "prova do crime" era um vídeo em que a docente explicava aos alunos as razões da greve docente. Já em 2016, ganhou destaque o caso da professora de sociologia 
Gabriela Viola, do Colégio Estadual Maria Gai Grendel, em Curitiba (PR), que foi afastada de suas funções por explicar o pensamento de Karl Marx em suas aulas. A acusação contra ela também foi de "doutrinação ideológica" (REVISTA FÓRUM, 2016).

Não obstante, convém lembrar que, ao passo em que o Movimento Escola Sem Partido tem ganhado força, também têm crescido grupos como Professores Contra o Escola Sem Partido ${ }^{7}$ e, à medida que a perseguição, os afastamentos e a censura se multiplicam, abrem-se mais espaços de debate acerca do tema, o que tem resultado em uma ampla agenda de seminários, manifestações e moções de repúdio em diversos espaços sociais.

Diante do atual cenário, qual é a função da escola? De modo geral, espera-se que a escola (e seus docentes) cumpram o que determina a lei. Tomemos então nossa Carta Magna, a Constituição Federal de 1988, segundo a qual a educação deve ter como objetivo "o pleno desenvolvimento da pessoa, seu preparo para o exercício da cidadania e sua qualificação para o trabalho" (BRASIL, 1988, art. 205, II). Os princípios para essa educação são vários, mas convém destacar um: "liberdade de aprender, ensinar, pesquisar e divulgar o pensamento, a arte e o saber" (BRASIL, 1988, art. 206, II).

A liberdade de ensinar é, portanto, uma conquista democrática, que se insere nos marcos pós-ditadura militar, já que, durante o regime de exceção, o magistério tornou-se uma profissão que demandava controle institucional, configurando-se como espaço de circulação e construção de conhecimentos que, por vezes, questionavam a ordem vigente. Naquele período, qualquer sinal de resistência ou crítica docente ao regime era classificado como atividade subversiva e, consequentemente, culminava em constrangimentos, violação de direitos humanos, perseguições, demissões, desaparecimentos forçados e até mortes.

Se, para alguns teóricos, a educação é um aparelho de reprodução da estrutura social, sem nenhuma possibilidade de mudar qualquer realidade, para outros, ela é uma prática sócio-histórica contraditória, que pode ser instrumento de conscientização e/ou também de dominação. Foi por uma educação para a conscientização que lutou Paulo Freire, contrapondo-se à educação com fins de dominação. Seu legado vai na contramão da oposição educador x educando, na qual o educando é a parte "fraca" da relação, como afirma o Movimento Escola Sem Partido. No pensamento freireano, a educação libertadora é feita através da categoria do diálogo e nela o professor não apenas ensina, mas também aprende no processo, não podendo existir nessa relação a fala "eu sou o professor e eu mando! ".

Em momento algum, Paulo Freire negou a responsabilidade e a diretividade do professor diante dos seus alunos, mas a diferença entre 
professor e aluno não faz com que estes sejam sujeitos antagônicos no processo educativo, mas, ao contrário, o professor deve caminhar juntamente com o aluno a fim de ultrapassar o saber ingênuo. Nesse processo, os educandos não são passivos e submissos, mas investigadores críticos, questionadores, que estão livres para construir novas leituras da realidade (FREIRE, 1987). Assim:

a educação libertadora, problematizadora, já não pode ser o ato de depositar, ou de narrar, ou de transferir "conhecimentos" e valores aos educandos meros pacientes à maneira da "educação bancária", mas um ato cognoscente. Como situação gnosiológica, em que o objeto cognoscível, em lugar de ser o término do ato cognoscente de um sujeito é o mediatizador de sujeitos cognoscentes, educador, de um lado, educandos, de outro, a educação problematizadora coloca, desde logo, a exigência da superação da contradição educador-educandos. Sem esta não é possível a relação dialógica, indispensável à cognoscibilidade dos sujeitos em torno de um mesmo objeto cognoscível (FREIRE, 1987, p.39).

Na perspectiva freireana, o professor não é o dono do conhecimento nem é o sujeito que impõe o que pensa para os alunos, ou seja, a educação freireana não pode ser um espaço de doutrinação, pois ela permite ser questionada e não se faz valer pelo autoritarismo. Esse posicionamento se manifesta até mesmo na seleção dos conteúdos programáticos, que devem ser selecionados de acordo com o que os educandos trazem de suas vidas. Por isso, o professor inclui na sua aula a vida concreta, desde a venda de balas no trem após a aula até o que o aluno não compreendeu do noticiário político. Essa articulação entre mundo real e sala de aula não é possível se tivermos professores sob constante suspeita e quando tal articulação é compreendida como mera doutrinação.

O argumento defendido pelo Movimento Escola Sem Partido de que o professor não pode expressar a sua visão de mundo em sala de aula coloca professores e alunos numa relação vertical, hierarquizada e desumanizada, confundindo radicalmente o ato de expor com o de impor ideias. Para nós, a apresentação do pensamento do professor sobre determinado assunto trata-se até de um ato de honestidade intelectual, esperado em uma relação mais próxima e verdadeira com os seus alunos. $\mathrm{O}$ aluno não teria direito de saber o que pensa o seu professor? O cuidado que se deve ter é apenas o de não massificar os alunos apenas com a vertente política ou ideológica do professor, como se outras leituras não existissem ou ocupassem lugar menos importante na aprendizagem dos alunos (VÁZQUEZ, 2002, p.56).

O Movimento Escola Sem Partido invoca uma ética, que é sinônimo de silenciamento docente, e mostra total desprezo pelo processo de mediação, 
assumindo uma posição radical entre "doutrinação" e silenciamento, optando por este. Já em Paulo Freire, a luta pela ética implica:

Vivê-la em nossa prática, [...] testemunhá-la, vivaz, aos educandos em nossas relações com eles. Na maneira como lidamos com os conteúdos que ensinamos, no modo como citamos autores de cuja obra discordamos ou com cuja obra concordamos. [...] Posso até não aceitar a concepção pedagógica deste ou daquela autora e devo inclusive expor aos alunos as razões por que me oponho a ela, mas, o que não posso, na minha crítica, é mentir (FREIRE, 1996, p.16).

Esse quadro de intolerância e radicalização é bem sintetizado por Frigotto (2016), para quem o Escola Sem Partido:

[...] trata-se da defesa, por seus arautos, da escola do partido absoluto e único: partido da intolerância com as diferentes ou antagônicas visões de mundo, de conhecimento, de educação, de justiça, de liberdade; partido, portanto da xenofobia nas suas diferentes facetas: de gênero, de etnia, da pobreza e dos pobres, etc. Um partido, portanto, que ameaça os fundamentos da liberdade e da democracia liberal, mesmo que nos seus marcos limitados e mais formais que reais (FRIGOTTO, 2016).

Dito isso, o que está sendo proposto é, além do controle do trabalho docente, um amplo processo de despolitização da educação, seguido da desvalorização do professor, retirando a liberdade de ensinar, de divulgar, eliminando a pluralidade de concepções pedagógicas garantidas pela LDB, impondo o interesse privado sobre o bem comum e enquadrando os alunos como sujeitos passivos no processo de aprendizagem, de modo que, conforme bem pontuou Pena: "Se eles [os alunos] se organizam em um movimento estudantil, só podem estar sendo manipulados pelos partidos de esquerda [...]" (PENA, 2016, p. 56). Nota-se que o objetivo maior da educação escolar, segundo o Escola Sem Partido, é a adequação dos sujeitos diante da realidade em que vivem, alinhando-se perfeitamente à educação bancária, para a qual, conforme apontado por Paulo Freire, quanto mais os sujeitos estão adaptados ao mundo, mais são considerados educados (FREIRE, 1987).

Sob o prisma ideológico, entendemos que o ato de educar é político e que a neutralidade reivindicada pelo Movimento Escola Sem Partido é, na realidade, uma ideologia que busca estar separada de seus criadores, ganhando status de autonomia epistemológica. Marx e Engels nos ajudam a compreender essa estratégia, que está na própria constituição da ordem burguesa. 
[...] se na concepção do curso da história separarmos as ideias da classe dominante da própria classe dominante e as tornamos autônomas, se permanecermos no plano da afirmação de que numa época dominaram estas ou aquelas ideias, sem nos preocuparmos com as condições da produção nem com os produtores dessas ideias, se, portanto, desconsiderarmos os indivíduos e as condições mundiais que constituem o fundamento dessas ideias, então poderemos dizer, por exemplo, que durante o tempo em que a aristocracia dominou dominaram os conceitos de honra, fidelidade etc. (MARX \& ENGELS, 2007, p.48)

Nessa direção, o Movimento Escola Sem Partido é uma das expressões contemporâneas de um processo histórico que se iniciou desde o estabelecimento da burguesia como classe dominante, pois esta passa a atuar no sentido de analisar o conhecimento e as ideias não como verdadeiras ou falsas, mas sim como úteis ou prejudiciais ao desenvolvimento do capital. Essa decadência ideológica se materializou no posicionamento político dos partidos burgueses, que abandonaram os ideais da revolução democrática burguesa à medida que constataram que a luta contra o feudalismo gerou uma cultura que se voltava contra a burguesia. Assim, foi necessário fomentar o"fim da ideologia", o"fim da história" e"paralelamente a este desprezo pelos fatos históricos, pelas reais forças motrizes da história, surge uma tendência à mistificação" (LUKÁCS, 2010, p.53). Ainda para o autor:

Não é possível que o homem supere em si mesmo os traços da decadência sem conhecer e compreender as mais profundas estruturas da vida, sem quebrar a casca superficial que, no capitalismo, recobre as ligações mais ocultas e a mais oculta unidade contraditória; aquela casca que a ideologia da decadência mumifica e vende como algo definitivo (LUKÁCS, 2010, p.81).

O conhecimento mistificado é apresentado como pronto, único e imutável, negando todas as contradições históricas, especialmente, a sua construção humana e social, presumindo estar acima de qualquer ideologia. Ao contrário disso, entendemos que a produção, a sistematização e a função social do conhecimento não estão fora da arena de lutas entre as classes sociais, logo, não estão à margem da política e da ideologia. Assim a ciência é "parcial, subjetiva, condicionada socioculturalmente e psicologicamente" (LEITE, 1994, p.13).

A produção e a função social do conhecimento sempre estão atreladas a determinadas concepções filosóficas. Tais concepções sempre são um modo de entender a relação entre os homens e destes com o mundo em uma determinada época. Desse modo, é impossível contrapor ideias 
autônomas versus matrizes ideológicas. A construção teórica está diretamente vinculada/condicionada a um processo histórico concreto (VASQUEZ, 2002).

A burguesia busca mistificar todas as determinações da construção social do conhecimento a fim de direcionar a educação cada vez mais como um processo de domesticação que alimente a ordem do capital. Atualmente, em nosso país, estratégias de coerção e de construção de consenso vêm sendo fomentadas com esse fim. Período semelhante ao contemporâneo viveram os educadores durante a ditadura militar, quando se fortificou internacionalmente o pensamento freireano. Portanto, para exemplificar a perseguição sofrida por Paulo Freire, na parte seguinte, apresentaremos dois documentos do SNI.

\section{Paulo Freire nos documentos da ditadura}

O primeiro documento associa Paulo Freire a um processo de doutrinação marxista por meio da educação escolar. Traz o histórico e a amplitude do trabalho político-pedagógico que ultrapassou as dimensões geográficas do estado de Pernambuco, alcançando vários países do mundo no contexto de seu exílio. Aliás, ao citar o exílio, o documento parece fazer crer que foi uma autovitimização, que não correspondia à realidade. Não obstante, acerca do exílio, Gadotti (1991) traz uma narrativa do próprio Paulo Freire, sobre sua prisão em junho de 1964: “Nega o senhor - perguntou-lhe um dos juízes - que seu método é semelhante ao de Stálin, Hitler, Perón e Mussolini? Nega o senhor que, com seu pretendido método, o que quer é tornar bolchevique o país?"(GADOTTI, 1991, p. 54). É possível perceber o nível agressivo e intimidador como Paulo Freire foi tratado, bem como a profunda confusão ideológica que tenta criminalizá-lo por múltiplas comparações desconexas. Ao contrário do que o documento da ditatura acusava, que o exílio era fruto de uma tentativa de autovitimização por parte de Paulo Freire, Gadotti esclarece que, "cansado de ficar sob vigilância rigorosa, cansado de ser chamado para responder perguntas, vendo que não podia fazer a única coisa que sabia fazer, e preferindo continuar vivo em lugar de se entregar a uma morte lenta, optou pelo exílio" (GADOTTI, 1991, p.54).

Quanto à educação libertadora, esta é descrita como a que teria o objetivo de "transformar a sociedade chamada de capitalista em uma sociedade comunista, a partir da doutrinação marxista-leninista aplicada nas escolas" (p.2). Na sequência, fica clara a preocupação da ligação entre Paulo Freire e setores da Igreja Católica. Na página 3, Paulo Freire é claramente tachado de "doutrinador esquerdista". 


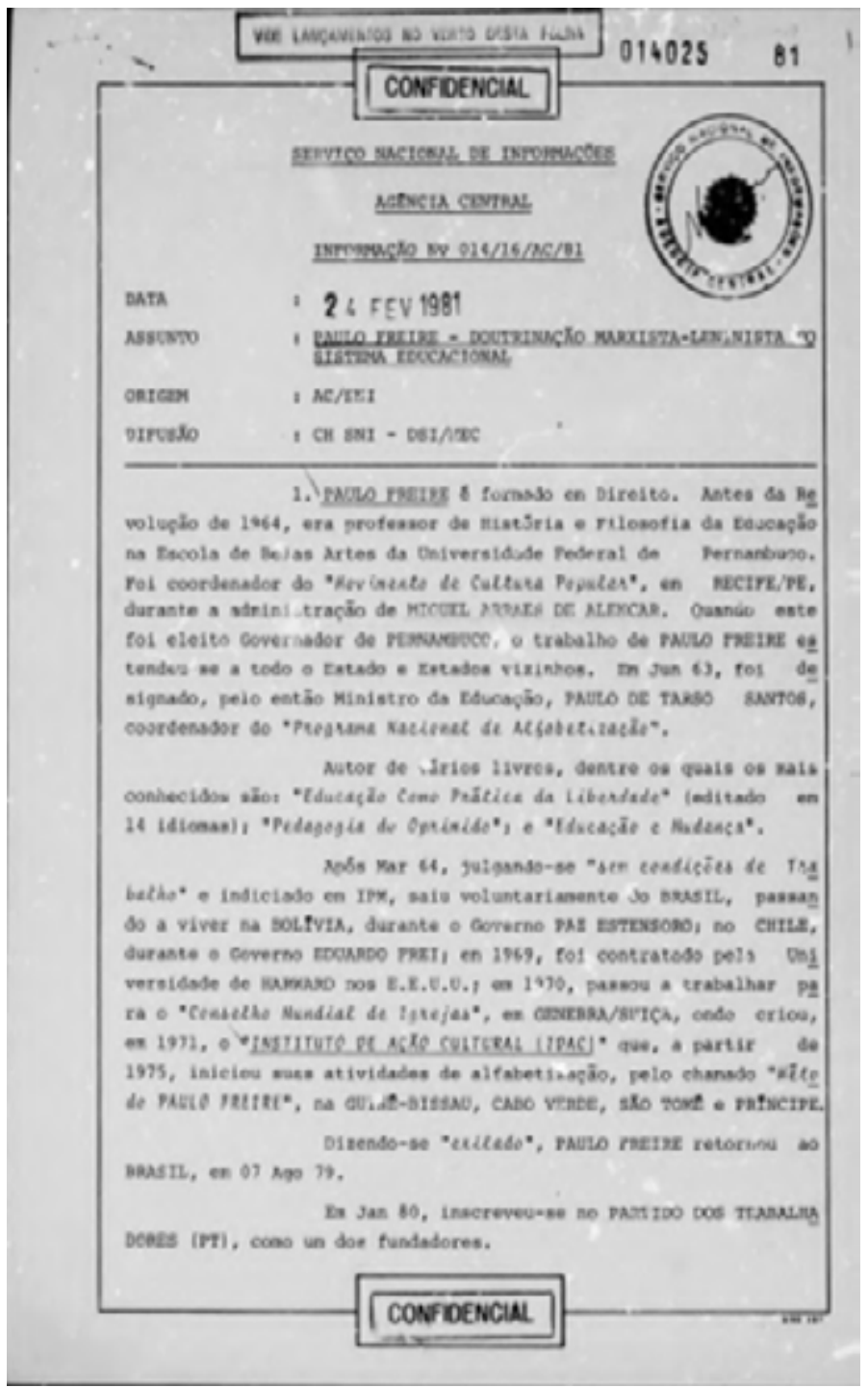




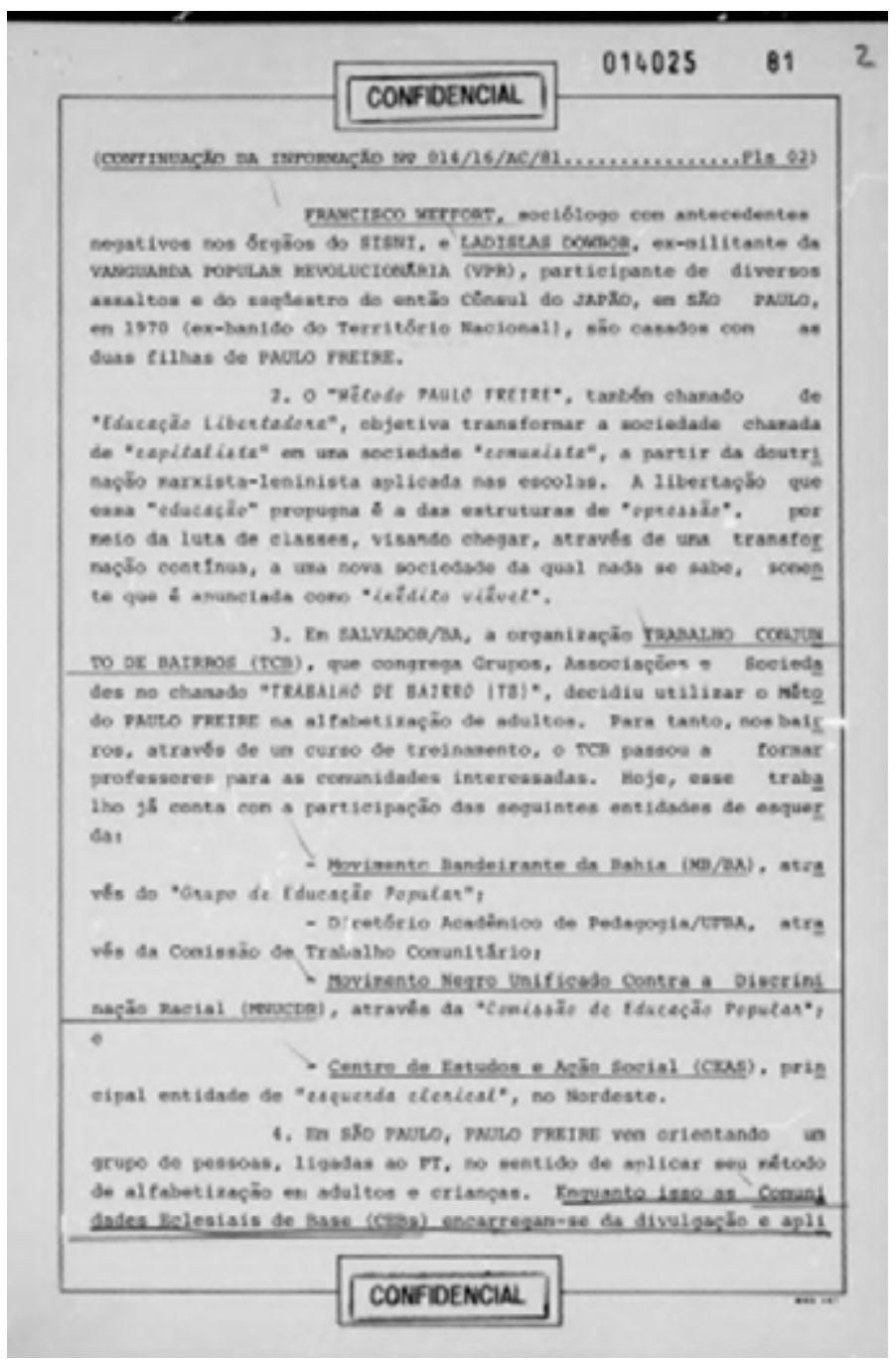




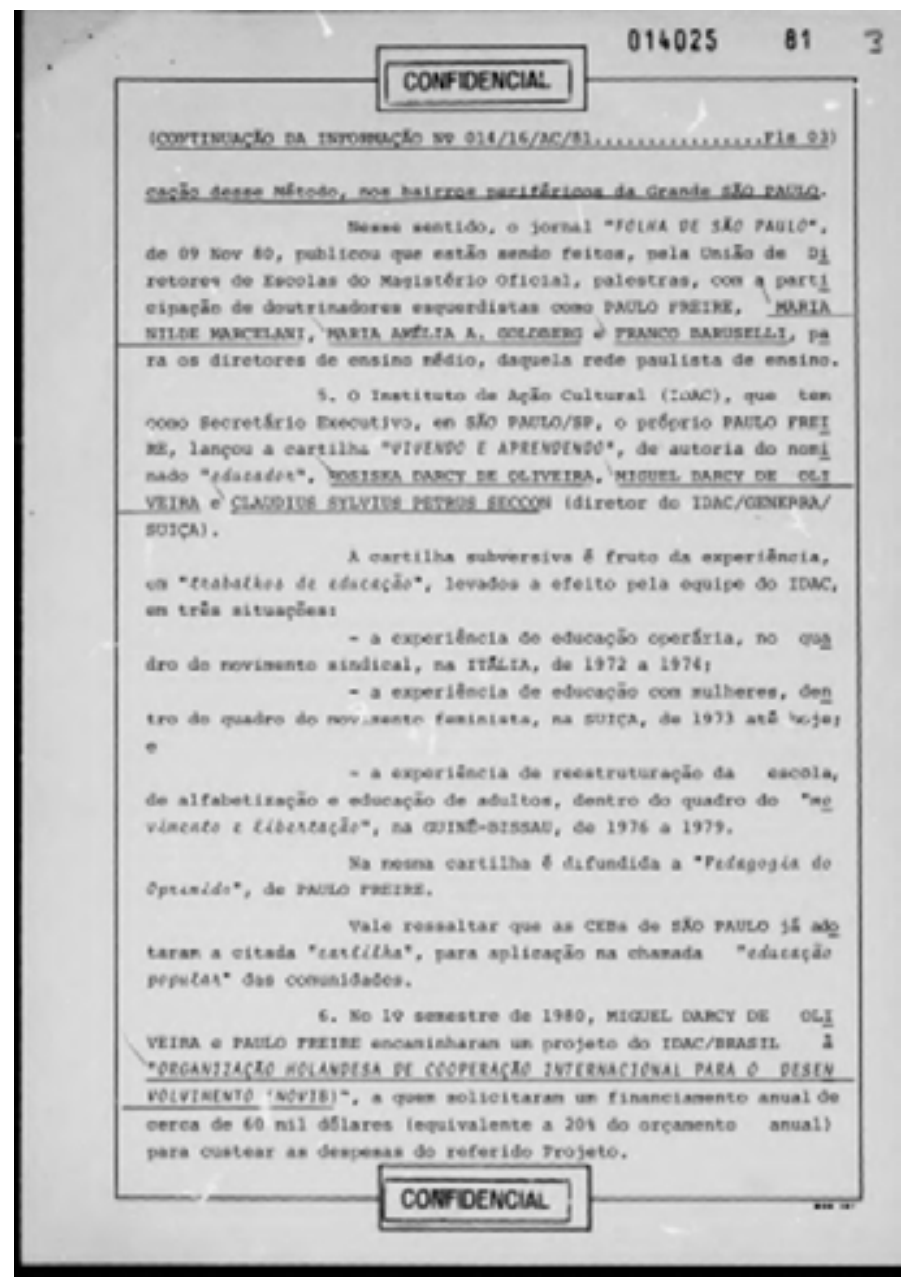

AC_ACE_14025_81. Fonte: Arquivo Nacional do Rio de Janeiro.

O segundo documento trata de uma pré-escola que estaria usando o "método Paulo Freire". O perigo desse método, acusa o documento, era fazer com que as crianças desde muito cedo passassem a questionar o mundo. Há também grande preocupação com a tentativa dos profissionais dessa préescola em aproximar a família da instituição para incentivá-la a participar do processo pedagógico, pois o verdadeiro objetivo por trás dessa integração seria a popularização do "método Paulo Freire" para que ele se tornasse oficial, ou seja, passasse a vigorar em todo o sistema de ensino. Vejamos. 


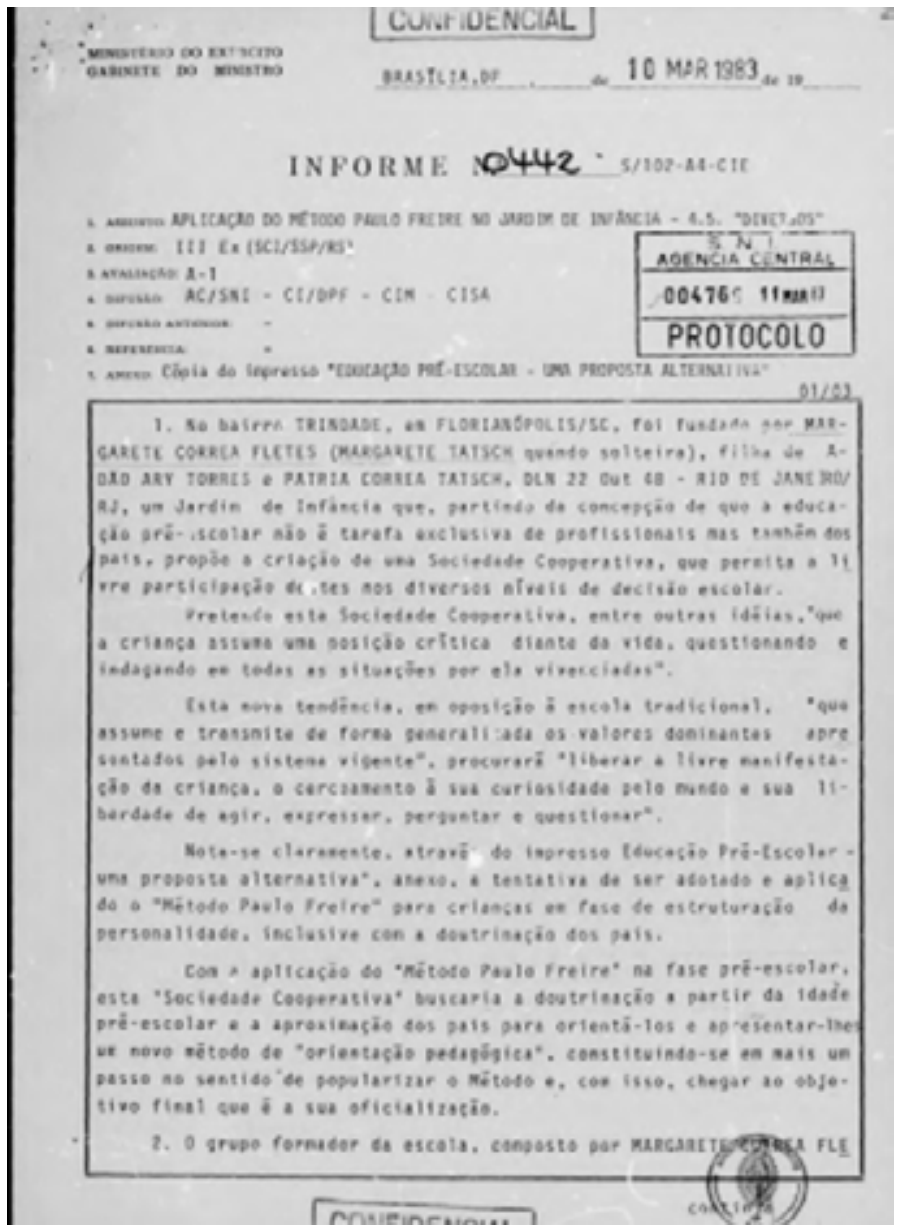




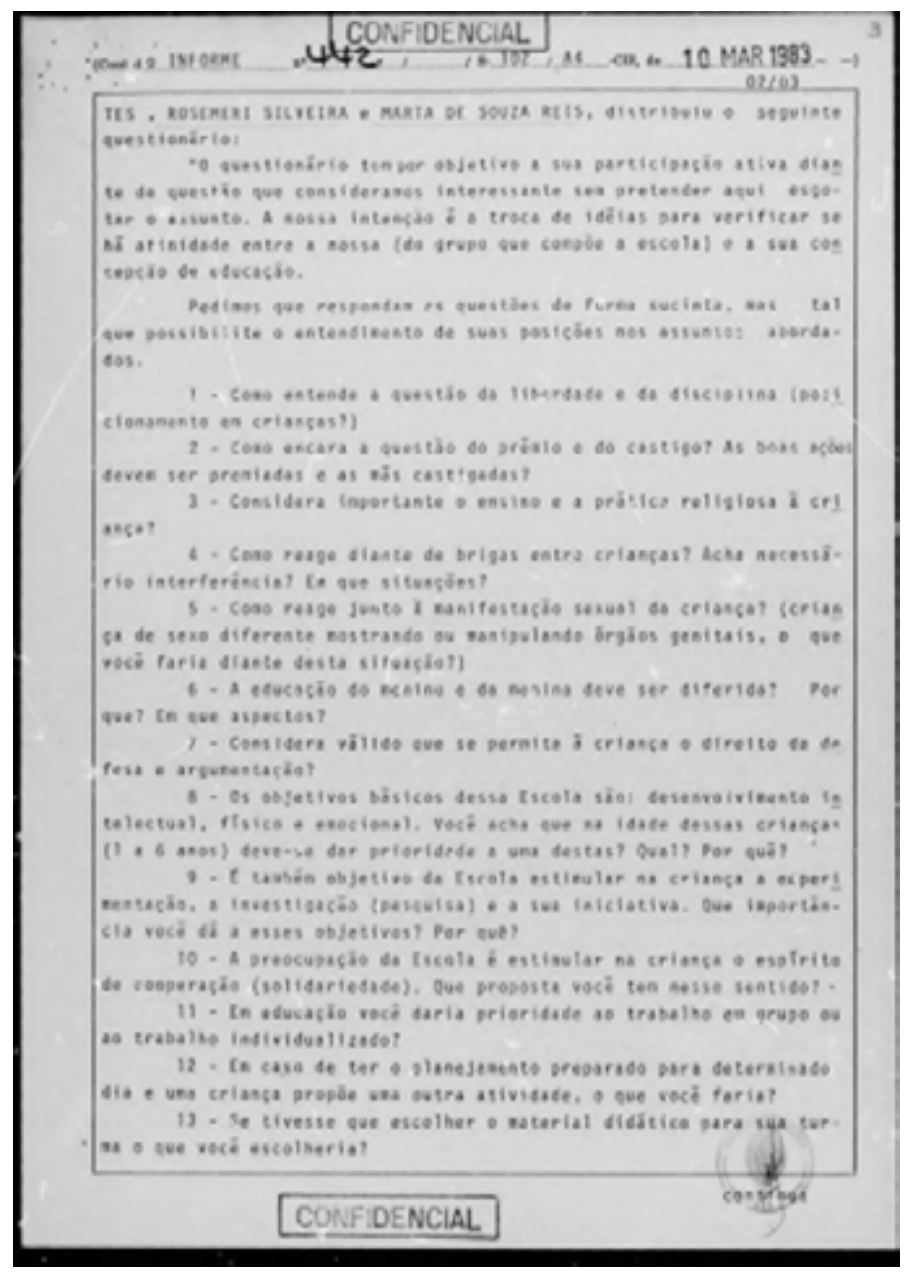

AC_ACE_31625_83. Fonte: Arquivo Nacional do Rio de Janeiro.

\section{CONSIDERAÇÕES FINAIS}

A partir do exposto, entendemos que não há no Brasil um exército de professores esquerdistas que doutrinam os alunos nas escolas. Porém, o que dizer de casos de professores que, de fato, desrespeitam os seus alunos $\mathrm{e}$ impõem os seus pensamentos como únicos e verdadeiros? A nosso ver, esses casos, "pontos fora da curva", não podem ser tomados como a totalidade do magistério. Além disso, essa ação antidialógica é a materialização da educação 
bancária combatida por Freire. Nem a educação bancária de esquerda nem a educação bancária de direita subsistem ao pensamento freireano. Nesse sentido, os que lutam verdadeiramente por uma escola sem "doutrinação" deveriam ter em Paulo Freire um verdadeiro referencial teórico.

Em Freire não há um método, uma fórmula pronta e imutável, mas sim um conjunto de princípios contra processos conformadores. Para ele, conscientização é um movimento de libertação, uma pedagogia construída pelo oprimido. Nessa direção, qualquer imposição é uma agressão, seja o pensamento de direita, seja o de esquerda. Também é agressão contra o professor acusá-lo de doutrinador apenas por expressar o seu pensamento. Entre extremos tão rígidos, talvez a melhor estratégia seja investir na formação de professores, na parceria família-escola, na conscientização necessária para que o divergente seja questionado, porém, respeitado. $O$ que não cabe em uma democracia é amordaçar os professores com uma lei que parte do princípio de que o aluno é "audiência cativa" de um professor que "abusa da liberdade de ensinar".

\section{FREIREAN THINKING IN TIMES OF SCHOOL WITHOUT PARTY}

ABSTRACT: The present article presents a brief reflection on the thought of Paulo Freire, having as background the debates that are about him in the context of the Movement Without Party School. In addition, we present documents from the military dictatorship that exemplify how Freirean thought was pursued at the time. It is an analysis that makes use of primary and secondary sources. We find that, despite living in different historical moments, the strategies of persecution seem similar, always associating the thought of Paulo Freire to processes of ideological indoctrination of the left. Indeed, in Freirean thought, the transfer/ imposition of knowledge on the part of teachers, from any political-ideological perspective, does not find shelter, because for him this is education and banking.

KEYWORDS: Paulo Freire. School without party. Military dictatorship. Indoctrination.

\section{PENSAMIENTO DE FREIRE EN TIEMPOS DE ESCUELA SIN PARTIDO}

RESUMEN: El presente artículo presenta una breve reflexión sobre el pensamiento de

Paulo Freire, fundamentándonos en los debates que se entrelazan sobre él en el marco 
del Movimiento sin Escuela del Partido. Además, presentamos documentos de la dictadura militar que ejemplifican como el pensamiento de Freire fue perseguido en la época. Es un que análisis hace uso de fuentes primarias y secundarias. Verificamos que, a pesar de vivir en diferentes momentos históricos, las estrategias de persecución parecen análogas, siempre asociando el pensamiento de Paulo Freire a los procesos de adoctrinamiento ideológico de izquierda. De hecho, en el pensamiento de Freire, la transferencia / imposición de conocimiento por parte de los profesores, desde cualquier punto de vista político-ideológico, no encuentra refugio, porque para él se trata de la educación bancaria.

Palabras-clave: Paulo Freire. Escuela Sin Partido. Dictadura militar. adoctrinamiento.

\section{NOTAS}

1) Há no site do Movimento Escola Sem Partido vários textos que se referem a Paulo Freire como doutrinador, bem como os seus "seguidores". Como exemplo ver: <http:// www.escolasempartido.org/artigos-top/382-paulo-freire-e-a-educacao-bancaria-ideologizada>. Na imagem, a cabeça de Paulo Freire aparece aberta com a frase: "Paulo Freire: transformando analfabetos inocentes em analfabetos comunistas desde 1963". Acesso em: 8 de nov. 2016.

2) Os documentos apresentados neste artigo estão guardados no Centro de Referência das Lutas Políticas no Brasil (1964-1985) - Memórias Reveladas, no Arquivo Nacional do Rio de Janeiro. Agradecemos a toda a equipe do Memórias Reveladas, em especial a professora doutora Inêz Stampa pela solicitude na pesquisa documental. Para maiores informações sobre o Centro de Referências, ver: < http://www.memoriasreveladas.gov.br/>.

3) Participaram do debate Miguel Nagib e o professor doutor. Fernando Penna, da UFF. Conferir em: <https://www.youtube.com/watch?v=J2v7PA1RNqk\&t=2948s>. Acesso em: 8 de nov. 2016.

4) Em resposta à ação movida pelo Sindicato dos Professores de Alagoas, a Procuradoria Geral da União considerou inconstitucional a "Lei da Escola Livre", aprovada pelos deputados, com redação dada pelo Movimento Escola Sem Partido. Ver: <http:// www1.folha.uol.com.br/opiniao/2016/10/1825209-partido-da-escola.shtml>. Acesso em: 26 out. 2016.

5) Convém lembrar que, no site do movimento, há dicas de como denunciar um professor "doutrinador". A página do Facebook é constantemente alimentada com vídeos-denúncia contra professores, aulas, eventos acadêmicos e manifestações políticas "doutrinadoras". Ver: <https://www.facebook.com/escolasempartidooficial/?fre $\mathrm{f}=\mathrm{ts}$ e http://escolasempartido.org/planeje-sua-denuncia>. Acesso em: 25 out. 2016. 
6) Termo cunhado por Daniel Caras, coordenador da Campanha Nacional pelo Direito à Educação. Ver: <http://educacaointegral.org.br/reportagens/especialistas-desconstroem-os-5-principais-argumentos-escola-sem-partido/>. Acesso em: 23 jan. 2017.

7) Ver: <https://www.facebook.com/contraoescolasempartido/?fref=ts $>$ Acesso em: 24 out. 2016.

\section{REFERÊNCIAS}

BRASIL. Constituição da República Federativa do Brasil. Brasília, DF: Senado Federal: Centro Gráfico, 1988.

. Senado Federal. Projeto de Lei no 193 de 2016. Inclui entre as diretrizes e bases da educação nacional o "Programa Escola sem Partido". Brasília (DF):2015. Disponível em: https://www12.senado.leg.br/ecidadania/visualizacaomateria?id=125666. Acesso em: 10 out. 2016.

Câmara dos Deputados. Projeto de Lei no 1411 de 2015. Tipifica o crime de assédio ideológico. Brasília (DF), 2015a. Disponível em: <http://www.camara.gov.br/ proposicoesWeb/fichadetramitacao?idProposicao=122980 > . Acesso em: 21 de out. 2016.

. Câmara dos Deputados. Projeto de Lei n 876 de 2015. Inclui entre as diretrizes e bases da educação nacional o "Programa Escola sem Partido". Brasília (DF), 2015b. Disponível em: <http://www.camara.gov.br/proposicoesWeb/fichadetramitacao?id Proposicao=1050668>. Acesso em: 14 out. 2016.

ESCOLA SEM PARTIDO. Planeje sua denúncia. Disponível em: <http://www.escolasempartido.org/planeje-sua-denuncia>. Acesso em: 24 jun. 2016.

FREIRE, P. Pedagogia do oprimido. 17 ed. São Paulo: Paz e Terra, 1987.

.Pedagogia da autonomia: saberes necessários à prática educativa. 33 ed. São Paulo: Paz e Terra, 1996.

FRIGOTTO, G. Escola Sem Partido: imposição da mordaça aos educadores. 2016. Disponível em: <http://cpers.com.br/escola-sem-partido-imposicao-da-mordaca-aos-educadores/>. Acesso em: 24 out. 2016.

GADOTTI, M. Convite à leitura de Paulo Freire. São Paulo: Ed. Scipione, 1991.

HOUAISS, A. Dicionário Houaiss da língua portuguesa. Rio de Janeiro: Ed. Objetiva, 2001.

LEITE, S. B. Considerações em torno do significado do conhecimento In: MOREIRA, Antônio Flávio Barbosa (Org). Conhecimento educacional e a formação do professor. São Paulo: Papirus Editora, 1994.

LUKÁCS, G. Marx e o problema da decadência ideológica. In: LUKÁCS, G. Marxismo e teoria da literatura. São Paulo: Expressão Popular, 2010.

MARX, K.; ENGELS, F. A ideologia alemã. São Paulo: Boitempo Editorial, 2007. 
NOGUEIRA, M. A. Um Estado para a sociedade civil: temas éticos e políticos da gestão democrática. 3 ed. São Paulo: Cortez Editora, 2004.

NAGIB, M. Escola Sem Partido: quem somos. Disponível em: <http://escolasempartido.org/quem-somos>>. Acesso em: 15 mar. 2016.

PENA, F. de A. Programa Escola Sem Partido: uma ameaça à educação emancipadora. 2016, p.43-58. Disponível em: <https://contraoescolasempartidoblog.files.wordpress. com/2016/07/programa-escola-sem-partido-uma-ameac3a7a-c3a0-educac3a7c3a3o-emancipadora.pdf >. Acesso em: 19 out. 2016.

RAMOS, M. S.; STAMPA, I. Subversão e resistência docente: notas sobre a ditadura militar e o Movimento Escola Sem Partido. Revista Espaço do Currículo, v. 9, n. 2, p. 249- 270, 2016.

REVISTA FÓRUM. A direita, a censura nas escolas, a mordaça ao pensamento crítico, o fascismo nu e cru no Brasil. 31 ago. 2016. Disponível em: <http://www.revistaforum. com.br/mariafro/2016/08/31/48633/>. Acesso em: 25 out. 2016.

VÁSQUEZ, A. S. Filosofia e circunstâncias. Rio de Janeiro: Civilização Brasileira, 2002.

\section{DOCUMENTOS}

AC_ACE_31625_83. Fonte: Arquivo Nacional do Rio de Janeiro.

AC_ACE_14025_81. Fonte: Arquivo Nacional do Rio de Janeiro.

Moacyr Salles Ramos é mestre em Educação pela Universidade Federal Rural do Rio de Janeiro (UFRRJ) e doutorando em Serviço Social pela Pontifícia Universidade Católica do Rio de Janeiro (PUC-Rio). É pedagogo na Faculdade de Educação da Universidade Federal Fluminense (UFF).

E-mail:mramos@id.uff.br

Ana Cecília dos Santos Santoro é licenciada em Letras (Português/ Francês) pela Universidade do Estado do Rio de Janeiro (UERJ) e mestranda em Educação pela Universidade Federal Fluminense (UFF). É técnica em assuntos educacionais do Centro Federal de Educação Tecnológica Celso Suckow da Fonseca (CEFET/RJ).

E-mail: anacssantoro@gmail.com 